\title{
'n Digter in Antwerpen: 'n Keuse uit die gedigte van Leonard Nolens, uit Nederlands vertaal deur Daniel Hugo
}

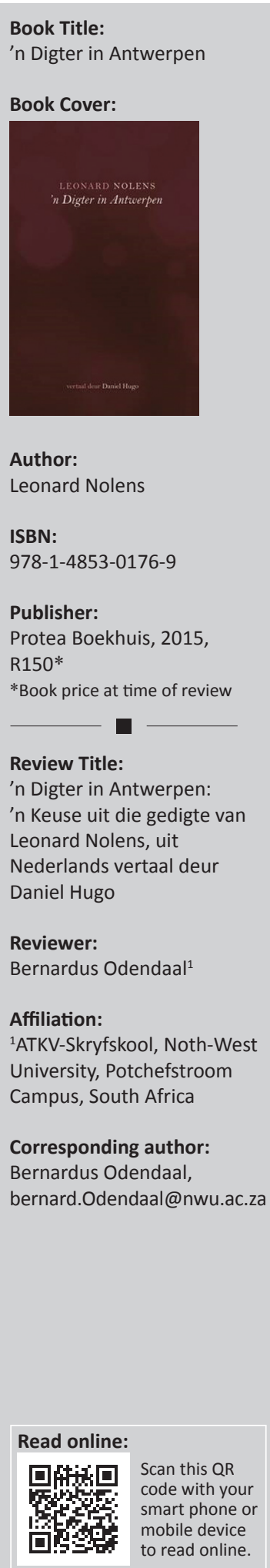

Die Vlaamse digter Leonard Nolens het sedert sy digdebuut in 1969 ' $n$ indrukwekkende oeuvre opgebou. Sy aansien as Nederlandstalige digter word onderstreep deur die talle literêre pryse wat aan hom toegeken is.

Vertaler Daniel Hugo en uitgewer Protea Boekhuis sorg nou dat 'n keur uit sy gedigte ook in Afrikaanse omsettings (geplaas langs die oorspronklike Nederlandse gedigte) die lig sien. Die gedigtekeuses laat die kollig sterk val op Antwerpen as ruimtelike agtergrond of onderwerp in Nolens se werk. Die stad tree soms as gespreksgenoot vir die digter op, byvoorbeeld in sommige verse uit Een dichter in Antwerpen en andere gedichten (2005), die Nolens-bundel waarvandaan Hugo die titel vir sy vertaalde keur oorgehewel het.

Nog 'n gespreksgenoot is die geliefde. Die stad en geliefde is trouens in die belewing van die digter nogal verweef. Grepe uit gedig 9 in die reeks " $n$ Digter in Antwerpen' lui byvoorbeeld:
Dit is haar vliegwerk, haar kordate lyfmusiek
Wat hier jou Vlaaikensgang binneloop, dit is
Haar asuurblou oë wat hier jou stegies
In die visier gekry het, al jou bedelaars groet.
[...]
'n Vrou is hier en nou my liriese verfyning
Van jou feite.
Haar matelose gevoel vir ritme hemel ons op.

Praggedigte soos dié bied insig in waarom Nolens as toonaangewende Nederlandstalige liefdeslirikus van die afgelope halwe eeu geag word. Alreeds hierom verdien die toeganklikmaking van Nolens se digterskap vir Afrikaanse poësielesers deur hierdie vertaalde keur lof. Vergelyk ook net die slotstrofe van 'Skatpligtig':
Ek is alleen saam met haar. Alleen saam met haar kom ek
Deur die jare aangeloop, want haar naam wys my die pad
En in haar oë sien ek my blinde tyd weerspieël.
Sy lê daar kaal en wit, 'n klip wat asemhaal,
Waaraan ek my hele stomp bestaan geslyp het en steeds
Slyp, ook wanneer ek slaap en roepend van haar droom.

Die digkuns self, en die digproses, die ontdekkings wat deur die worsteling met die taal gemaak word, is ' $n$ ander belangrike tematiese kompleks in Nolens se werk. Hoe avontuurlik ook, digwerk is geen maklike taak nie. Dis vol spanningsvelde (uit: Paranoia):

\footnotetext{
Ek kan dit ook nie help nie, die subliemste prosodie

Kom uit die derms, elke siel dink finaal intestinaal.

$[\ldots]$

Dit bekoor of oordonder dalk. Dit is nie so bedoel nie.

Baie van hierdie reëls is met haat en nyd aanmekaargetimmer,

Maar ook met goeie bedoelings, my pad loop reguit hel toe.

Dié wat ly, gaan hel toe; pyn verdien nie punte nie.
}

Nie verniet nie word digterskap deur Nolens gesien as 'n lewenstaak wat wesenlike vereensaming in die hand werk. Die geliefde voel byvoorbeeld daardeur vervreem. Passasies uit die aangrypende 'Bruilofslied' lui soos volg:

How to cite this book review: Odendaal, B., 2017, "n Digter in Antwerpen: 'n Keuse uit die gedigte van Leonard Nolens, uit Nederlands vertaal deur Daniel Hugo', Literator 38(1), a1306. https://doi.org/10.4102/lit.v38i1.1306

Copyright: ( 2017. The Authors. Licensee: AOSIS. This work is licensed under the Creative Commons Attribution License. 
Jy het dit al so dikwels gehaat, jy haat

My liefde vir hierdie kluisenaarsbestaan, jy haat

$[\ldots]$

My obsessies, deesdae, in hierdie stamelende studio

Hier aan die rand van die stad, o jy haat my liefde.

Jy haat dit om te figureer hier in hierdie kamer

Sonder ons, jy haat die blou son van jou blik

Op hierdie kaal blad [...]

[...]

‘Ek is nie jou versinsel van dertig jaar nie.

Bly hier. Bly hier by my.

Ek haat jou bruilofslied.'

Die liries persoonlike aanslag, die in-kennigheid van baie van sy verse, dit waaroor Nolens op boeiend relativerende wyse in 'n gedig soos 'Ek' besin, tref 'n mens - des te meer as jy vanuit 'n bewoë polities maatskaplike bedeling soos die SuidAfrikaanse een lees. Terselfdertyd kom jy onder die indruk van die wyse waarop die taalgedrewe benadering, die raak beelding en die ironiese blik verhoed dat in sentimentaliteit verval word. Bowendien, soos die slotstrofe van 'Sosiale betrokkenheid' lui:

Moet ek die TV-nuus beween met volwasse oë?

Jy het ' $n$ groot pyn aan die ander kant van die aarde
Of hier in my straat, en ek het myne, klein, privaat

En wêreldvreemd, sê jy. Maar vreemd aan watter wêreld?

Onlangs is die Prestasieprys van die Van Ewijck-stigting aan Hugo toegeken vir sy brugbouerswerk tussen Suid-Afrika en die Nederlande, waaronder veral sy rol as vertaler van meer as 50 Nederlandse boeke in Afrikaans gereken word. Hy is ook al deur die Suid-Afrikaanse Akademie vir Wetenskap en Kuns vir sy vertaalwerk bekroon.

As ervare digter (met 15 eie digbundels agter sy naam) is hy as 't ware in die wieg gelê om digwerk in Afrikaans om te sit. Dié werk, sy sewende vertaalde keur uit werk van prominente Nederlandstalige digters die afgelope twee dekades, is 'n klinkende bewys hiervan - sóós sy Afrikaanse omsettings van Eduard FitzGerald se (oorspronklik Engelse weergawes van) Die roebaijat van Omar Khajjam. Derhalwe beklee Hugo 'n sentrale plek in 'n ontwikkeling binne die Afrikaanse letterkunde wat sedert die sosiopolitieke omwentelings van die vroeë 1990's in Suid-Afrika opvallend geword het: 'n verhewigde nasionale en internasionale wisselwerking. 